\title{
Exploring small and medium industry stakeholders' perspectives of halal certification in Indonesia: A case of Bangkalan Regency, Indonesia
}

\author{
L. Qadariyah* \& S. Nahidloh \\ Universitas Trunojoyo, Madura, Indonesia \\ A.I. Mawardi \\ Universitas Islam Negeri Sunan Ampel, Surabaya, Indonesia
}

\begin{abstract}
Halal certification is enacted to respond to the public anxiety of safe food products from forbidden materials based on Islamic rules. Anchored by small studies exploring halal certification perspectives among small and medium industry stakeholders in an Indonesian context, the present study was enacted to uncover these stakeholders' perspectives of halal certification. Fifteen small and medium industry owners (henceforth, participants) in Bangkalan, Madura, Indonesia, were involved in an interview. Findings suggest that the participants view halal certification as an essential aspect for selling their products. Also, due to the complicated process of achieving the halal certification label, most of their products are not certified.
\end{abstract}

Keywords: halal certification, small and medium industry, perspective

\section{INTRODUCTION}

Small and medium industry (SMI) is a business unit that has an essential role in developing a community's economy. Besides being able to increase foreign exchange income for the country, this business unit can also help increase lower-class income. According to the Indonesian Ministry of Industry, it is explained that, in 2018, SMI could absorb a workforce of 17.9 million people and absorb $60 \%$ of the industrial workforce (Kemenperin 2019). These attainments have been seen as very significant in many countries, including Indonesia.

In Indonesia, SMI provides an ample contribution to national industrial development. In fact, $43.41 \%$ or 1.86 million are food sellers. At certain events, this percentage, especially in the food sector, increases due to the growing number of requests, such as before the Idul Fitri and other public holidays. Due to the large potential SMI brings, it is not surprising that the government also cares for them. Through capital assistance, routine coaching, and regular assistance, the government desires to develop the quality and quantity of SMI, including helping them in product halal certification. The halal status of a product has now become one of the considerations for consumers during the explosion of products that use non-halal ingredients, such as pork oil. It is explained in the Qur'an (Al-Maidah, 88):

O you who believe, do not prohibit what Allah has made legal for you, and do not transgress. Indeed, Allah does not like those who transgress. And eat food that is clean and good, from what Allah has blessed you with and fear Allah whom you believe in Him.

Apart this verse, there are many other verses that instruct Muslims to pay attention to the halal and thoyyib consumption. According to al-Syatibi, Sharia law is principally aimed at realizing the

\footnotetext{
${ }^{*}$ Corresponding author
} 
benefit of mankind (Syatibi 2003). This means that all the commands and prohibitions of Allah to humans are for the good of humans themselves. When Allah commands people to consume halal food and thoyyib, there must be a reason for it whose purpose is to protect the human's life, soul, health, and others things.

This secret was then revealed through several studies that focused on discussing the positive effects of consuming halal food (Azeez 2013), including health and moral intelligence, psychology, and even a positive impact on human development in general (Arif \& Ahmad 2011; Deuraseh 2014; Md. Sawari et al. 2015). Based on these advantages and also evidence of adherence to religious rules, the Institute for the Study of Food, Medicine, Cosmetics under the Indonesian Ulama Council enacted an initiative to certify or provide halal labels for food products that do not contain forbidden ingredients. This halal label, in its development, has become a trend not only in Indonesia but also abroad and is a potential market that is projected to continue to increase in the future (Elasrag 2016; Islam 2012).

This large potential is not only influenced by the increasing population of Muslims in the world (Global Islamic Economy Report 2019) but also the interest of non-Muslims to buy and consume halal products which for them are cleaner, more hygienic, and healthier (Atiah \& Fatoni 2019; Hassan \& Hamdan 2013; Mathew et al. 2014). With these considerations, the Indonesian Ulama Council is targeting that products circulating in Indonesia, whether from abroad or, especially domestic products must be certified starting October 2019. This policy continues to strive to meet these targets by working with mass organizations, universities, and several parties to become partners as a halal guarantee institution and which is also a mouthpiece for information on the importance of certification through education and mentoring programs. One of the targets of this program is small and medium industry sectors.

In the Bangkalan Regency, Indonesia, it was found that $130 \mathrm{SMI}$ are in this area, according to a report by the Industry service. Most of the SMIs are engaged in the food sector, characterized by Madurese culture food. Unfortunately, most of them do not have halal certification. Therefore, the present study was designed to reveal how SMI stakeholders view halal certification. The findings are expected to shed light of the importance of intensive education and coaching for SMI stakeholders enacted by the Department of Industry and Trade.

\section{METHODS}

This study employed a qualitative approach that aims to describe holistically the small and medium industry stakeholders' perspectives of halal certification. Data was gathered through interviews with fifteen owners of this small and medium industry in Bangkalan, Madura, in the province of East Java, Indonesia. The data was analyzed using a reduction stage. We first carried out a data selection process, focusing on simplification, abstracting, and transforming data collected from written notes. Later, data presentation was carried out in the form of data preparation for drawing conclusions.

\section{RESULTS AND DISCUSSION}

\subsection{Legal basis for halal certification}

The legal basis for the enforcement of halal certification is derived from Sharia law (al-hukmasysyar' $i$ ). To ensure the enforcement of these Sharia provisions in relation to the law of halal and haram, procedural regulations (al-hukm asy-syar'i) are needed. The legal basis for the validity of halal certification is as follows:

Then eat what is lawful and good and the sustenance that Allah has given you, and be thankful for Allah's blessings, if you only worship Him (Surah An-Nahl [16]: 114).

In connection with the recommendation to eat and drink lawful food or beverage, several verses have informed these, including Surah al Baqarah, 168, and Nahl 114, al Midah 88. Consumption 
in Islam is limited by Sharia rules, where there are several things that are halal and haram for consumption (Havis 2017). For the Islamic society, consuming what is lawful and good (thayyib) is a manifestation of devotion to Allah. Muslim consumers' behaviour is different from non-Muslim consumers. Muslim consumers, both in terms of production and consumption, are bound by Islamic rules, meaning that the freedom related to the production and consumption activities is regulated. Since Islam prohibits a Muslim from consuming several commodities, such as alcohol and pork, then even in the production of food it is prohibited to use these ingredients (Al-Teinaz et al. 2019; Alzeer et al. 2018). Therefore, the existence of a halal label guarantees that the food is protected from things that are prohibited in Islam.

\subsection{Halal certification in the perspective of small and medium industry (SMI) stakeholders in Bangkalan Regency, Indonesia}

As mandated by Law No. 33 of 2014, in 2019, all halal products spread across Indonesia, both local and foreign products, are required to have a halal label. This mandate is enacted by the government so that the domestic industry can compete in the world halal industry which is currently a potential market. Therefore, it is not surprising that the government, through several related agencies, makes such efforts to be able to teach the importance of the halal label and also provide intensive guidance to them regarding the halal labelling process.

In Bangkalan regency, SMI under the governance of the Department of Industry and Trade have received trainings on halal certification and labelling, despite efforts to the contrary. In terms of halal certification and labelling, food is quite different from other products. In this regard, in order to obtain a halal certificate, the raw materials, production process, expiration period, and nutrition are required and objectively observed. Therefore, SMI that have accomplished these processes is given halal certification and labialization as formal proof that the products sold are well-guaranteed for halal consumption.

Our interview with fifteen SMI owners shows that the participants view halal certification as an essential aspect for product selling and consumption. They believe that products with a halal label can be ascertained to be of good quality and are safe to consume. This perspective is seen as a picture of Madurese religious and cultural characteristics. These cultural specificities are seen in their hierarchical obedience, submission, and surrender to the four main figures such as father (bhup-pa'), mother (bhabbu'), teachers (ghuruh) and government (ratoh) (Wiyata 2020). In religious practice, Madurese society strongly adheres to the teachings of their religion. Islamic symbols are central and become a serious concern, including the need for a halal label.

We also discovered that $33.3 \%$ of the participants in this study are not consistent in checking the halal label on the materials to be used in the products by arguing that they do not need to check as the products are natural ingredients such as herbal medicine. It can be concluded that they consider it unimportant to check halal materials in the products since the materials such as cooking oil and sugar are their basic ingredients for the products. For instance, regardless of the products, sugar is taken from sugar cane and cooking oil from coconut which naturally makes these materials halal.

The participants' understanding on these natural halal materials are derived from Madurese cultures (Wiyata 2020). they will do anything according to their beliefs and knowledge. When they believe that an item is halal, even if there is no halal logo, it will be considered lawful for consumption. In a similar vein, Madurese people are consistent in upholding their religious principles, including for haram product consumption (Jonge 1989; Rifai 2007; Subaharianto 2004).

Based on Madurese understanding, halal food does not contain khamr, pork, and others. The aforementioned understanding refers to a global material which excludes pork oil and skin, as explained in Surah al Maidah, 3:

It is forbidden for you to (eat) carcasses, blood, pork, (animal meat) that were slaughtered in the name other than Allah, those who were strangled, those who were beaten, those who fell, who were gored, and were killed by wild animals, except those you had slaughtered them, and (forbidden). for you) who were slaughtered for idols (al Maidah: 3 ). 
In the context of the halal label, the participants also viewed it as an important element in convincing consumers, albeit some of the participants rarely check for the halal label. It indicates that the halal label has been a requirement for selling halal-guaranteed products and can help consumers to avoid deception. When examined from the theory of producer behavior in Islam, producers in Islam are required to implement moral values following the Qur'an and Hadith in terms of meeting consumers' needs, production processes, obtaining capital, business growth, and diversification for business continuity (Sukarno 2010).

Some of the participants in this study argued that a halal label can also be used to increase their sales quantity as previous research has shown (Hanim Yusuf et al. 2016). These SMI owners also have a good perception of the relationship between halal labels and increased sales. Most of the participants (13 out of 15) believed that this halal label affects the level of sales, since with this halal label, the product is well accepted in the middle of society. When asked whether they had the desire to register their products in order to obtain halal certificates and labels, $60 \%$ stated that they had the desire to register their products as products with a halal label, $6.7 \%$ stated that they already had a halal label on their products, and equal to $20 \%$ stated that they were in the process of certification and labelling and $13 \%$ did not answer these questions. Most of the reasons why they do not have halal certificates until now are because of the cost which is considered quite expensive and the process is quite long. Our findings should use as catalysts for the Indonesian government to enact society-based policies, especially in the halal certification sector.

\section{CONCLUSION}

This study has shown that, from the perspectives of small and medium industry stakeholders, halal certification is a central aspect for traded products. This label is quite influential in increasing sales circulation. However, despite the halal label significance in a product, very few of the participants involved in this study checked the product halal ingredients. In other words, their understanding of halal certification is seen in this study, but their sustained attention to halal ingredients is not held.

\section{REFERENCES}

Al-Teinaz, Y. R., Spear, S., \& Abd El-Rahim, I. H. A. (Eds.). 2019. The halal food handbook. John Wiley \& Sons, Inc.

Alzeer, J., Rieder, U., \& Hadeed, K. A. 2018. Rational and practical aspects of Halal and Tayyib in the context of food safety. Trends in Food Science \& Technology, 71, 264-267. https://doi.org/10.1016/j.tifs.2017.10.020.

Arif, S., \& Ahmad, R. 2011. Food quality standards in developing quality human capital: An Islamic perspective. Afican Journal of Business Management, 5 (31).

Atiah, I. N., \& Fatoni, A. 2019. Sistem Jaminan Halal: Studi Komparatif Indonesia dan Malaysia. Syi'ar Iqtishadi: Journal of Islamic Economics, Finance and Banking, 3(2), 37. https://doi.org/10.35448/ jiec. v3i2.6585.

Azeez, W. 2013. The Halal Dietary System as a Recipe for Good Health. IOSR Journal of Humanities and Social Science, 7(4), 7.

Deuraseh, N. 2014. Islamic Dietary Habit for Preservation of Health: A Review from Islamic Literature. Middle East Journal of Scientific Research, 20 (2), 7. https://www.researchgate.net/pro-file/Nurdeng_Deuraseh/ publication/305298866_Islamic_Dietary_Habit_for_Preserva-tion_of_Health_A_Review_from_Islamic_ Literature/links / 57872e2608aef321de2c7a15/Islamic - Die - tary-Habit - for - Preservation - of - Health -AReview-from-Islamic-Literature.pdf.

Elasrag, H. 2016. Halal Industry: Key Challenges and Opportunities. SSRN Electronic Journal. https://doi. org/10.2139/ssrn.2735417. Global islamic Economy Report. 2019.

Hanim Yusuf, A., Abdul Shukor, S., \& Salwa Ahmad Bustamam, U. 2016. Halal Certification vs Business Growth of Food Industry in Malaysia. Journal of Economics, Business and Management, 4(3), $247-251$. https://doi.org/10.7763/JOEBM.2016.V4.399.

Hassan, S. H., \& Hamdan, H. 2013. Experience of Non-Muslim Consumers on Halal as Third Party Certification Mark in Malaysia. Asian Social Science, 9(15), p263. https://doi.org/10.5539/ass.v9n15p263. 
Havis, A. 2017. Sejarah Pemikiran Ekonomi Islam Kontemporer. PT. Kharisma Putra Utama.

Islam, T. 2012. Halal Marketing: Growing Pie. International Journal of Management Research and Review, 3(12), 11.

Jonge, H. D. 1989. Madura dalam Empat Zaman: Pedagang, Perkembangan, Ekonomi dan Islam: Suatu studi Antropologi Ekonomi. Gramedia.

Kemenperin. 2019. IKM Berkontribusi 60 Persen Serapan Total Tenaga Kerja Industri. IKM Berkontribusi 60 Persen Serapan Total Tenaga Kerja Industri.

Mathew, V. N., Abdullah, A. M. R. binti A., \& Ismail, S. N. binti M. 2014. Acceptance on Halal Food among Non-Muslim Consumers. Procedia - Social and Behavioral Sciences, 121, 262-271. https://doi.org/10. 1016/j.sbspro.2014.01.1127.

Md. Sawari, S. S., Ghazali, M. A., Ibrahim, M. B., \& Mustapha, N. I. 2015. Evidence Based Review on the Effect of Islamic Dietary Law Towards Human Development. Mediterranean Journal of Social Sciences. https://doi.org/10.5901/mjss.2015.v6n3s2p136.

Rifai, A. M. 2007. Manusia Madura: Pembawaan, Perilaku, Etos Kerja, Penampilan dan Pandangan Hidupnya Seperti dicitrakan Peribahasanya. Pilar Media.

Subaharianto, A. 2004. Tantangan Industrialisasi Madura: Membentuk Kultur, Menjunjung Leluhu. Bayumedia.

Sukarno, F. 2010. Etika Produksi Perspektif Ekonomi Islam. Jurnal Ekonomi Islam al Infaq, 1(1), 13.

Syatibi, A. I. al. 2003. Al Muwafaqat fi Usul al Syariah Jilid I Cet III. Dar Kutub al Ilmiyah.

Wiyata, L. 2020. Carok; Konflik Kekerasan dan Harga Diri Orang Madura. LKiS. 